\title{
Postlarval development of Nicolea uspiana (Polychaeta: Terebellidae)
}

\author{
André R. S. Garraffoni ${ }^{1,2} \&$ A. Cecília Z. Amaral ${ }^{1}$ \\ ${ }^{1}$ Departamento de Ciências Biológicas, Universidade Federal dos Vales do Jequitinhonha e Mucuri. Campus II, \\ Rodovia BR-367, 39100-000 Diamantina, Minas Gerais, Brasil. E-mail: garraffoni@gmail.com \\ 2 Departamento de Zoologia, Instituto de Biologia, Universidade Estadual de Campinas. Caixa Postal 6109, \\ 13083-970 Campinas, São Paulo, Brasil.
}

\begin{abstract}
The postlarval development of Nicolea uspiana (Nogueira, 2003), a small intertidal terebellid polychaete from rocky habitats on the southeastern and southern Brazilian coast, was studied based on postlarval, juvenile and adult specimens. The specimens, ranging from 8 to 43 segments, were collected between May 2006 and May 2007. The youngest postlarval specimen was found crawling outside of the tube. In specimens at different stages of growth, the number of ocelli and tentacles increased; the first pair of nephridial papillae appeared early (before 8-segmented specimen), and the second and third pairs appeared later (31-segmented specimen); the circulatory system only developed when the first pair of branchial bulbs arose (32-segmented specimen), and the second branchial pair appeared later (40-segmented specimen); and the inversion of the uncini positions in some rows occurred in the transition from larva to juvenile (17-segmented specimen). In the course of development, segments 2-3 lost the notochaetae, and segments 3-4 lost the neurochaetae. The changes involved in the development from postlarval to adult animals are illustrated by SEM micrographs and photographs.
\end{abstract}

KEY WORDS. Brazil; Nicolea; ontogeny.

The great diversity in the mode of development of marine invertebrates is a challenge for scientists who seek to understand the evolution of life-history patterns (McHugH \& RousE 1998). Biologists have long recognized the large diversity of spawning, fertilization, development of the feeding larval stage, brooding and metamorphosis in polychaetes (WILSON 1991, Rouse \& Fitzhugh 1994). However, very little research has been conducted on the initial developmental stages of some groups of polychaetes, such as Terebellidae (BLAKE 1991).

Nicolea uspiana (Nogueira, 2003) is a gregarious sedentary terebellid that constructs mucous tubes covered by sand grains and shell fragments in the midst of aggregates of algae, ascidians, hydroids, and bryozoans. This species is commonly found in the intertidal zone of rocky shores, always as dense populations with large numbers of individuals in different stages of maturity (NogueIra 2003). It has been reported from the Brazilian coast, in the states of São Paulo (23⒌'S, $46^{\circ} 22^{\prime} \mathrm{W}$, Nogueira 2003) and Paraná (25033'88”S, 48¹9'14"W, BlanKensteyn \& MoReno 1999).

This study describes the postlarval ontogenetic development of N. uspiana, with emphasis on the modifications of the cephalic structures, branchiae, nephridial papillae, circulatory system, and anterior noto- and neurochaetae.

\section{MATERIAL AND METHODS}

From May 2006 to May 2007, postlarval, juvenile and adult specimens of N. uspiana were collected monthly in the intertidal zone along the rocky shore of Porchat Island, on Itararé Beach
(235' $35^{\prime \prime}$ S, 46²3'15”W, São Vicente, Brazil). The local intertidal sediment is a mixture of sand and rock fragments of different sizes. Spring tides are less than two meters in amplitude, characterizing a regime of microtides (FurTADO \& MAHIQUES 1990).

The tubes of coarse sand and shell fragments were collected and stored in an insulated box, transported, and maintained in an aquarium at the laboratory of the Department of Zoology, Institute of Biology, State University of Campinas. In the laboratory, the specimens were sorted, while fresh and unfixed, using a binocular microscope. The sorted specimens were anesthesized in a solution of seawater and magnesium chloride for about one hour, fixed in $6 \%$ formalin for at least 48 hours, and then transferred to $70 \%$ ethanol for storage.

Photographs of the living relaxed specimens were taken with a digital camera mounted on a Zeiss KS100 microscope. The drawing was prepared with the aid of a camera lucida. The specimens used for scanning electron microscopy were dehydrated in an ethanol series, critical-point-dried in $\mathrm{CO}_{2}$ and coated with a thin layer of gold ( $25 \mathrm{~nm})$. Observations of the material were made in the Microscopy Laboratory, IB-UNICAMP.

Specimens were deposited in the Zoological Museum of the State University of Campinas (ZUEC-POL 1967-1970).

\section{RESULTS}

The smallest individual had eight segments (Tab. I) and moved freely, but slowly, on the outer surface of tubes occupied by other individuals of $N$. uspiana. The body was slightly ex- 
Table I. Nicolea uspiana: morphological features in individuals of different sizes. (+) Present, (-) absent or no information, (bb) branchial bulb, (b) branchia.

\begin{tabular}{|c|c|c|c|c|c|c|c|c|}
\hline $\begin{array}{l}\text { Number } \\
\text { segments }\end{array}$ & $\begin{array}{l}\text { Number } \\
\text { eyespots }\end{array}$ & $\begin{array}{l}\text { Number } \\
\text { tentacles }\end{array}$ & $\begin{array}{c}\text { First segment } \\
\text { with notochaeta }\end{array}$ & $\begin{array}{c}\text { Segments with } \\
\text { nephridial papillae }\end{array}$ & $\begin{array}{l}\text { Number segments } \\
\text { with notopodia }\end{array}$ & Row of uncini & Branchiae & $\begin{array}{c}\text { Circulatory } \\
\text { system }\end{array}$ \\
\hline 8 & 4 & 1 & 2 & 2 & 5 & simple & - & - \\
\hline 9 & 4 & 1 & 2 & 2 & 6 & simple & - & - \\
\hline 9 & 4 & 1 & 2 & 2 & 6 & simple & - & - \\
\hline 10 & 4 & 1 & 2 & 2 & 7 & simple & & \\
\hline 10 & 4 & 1 & 2 & 2 & 7 & simple & - & \\
\hline 11 & 4 & 1 & 2 & 2 & 7 & simple & - & - \\
\hline 11 & 4 & 1 & 2 & 2 & 7 & simple & - & \\
\hline 12 & 6 & 2 & 2 & 2 & 7 & simple & & \\
\hline 12 & 4 & 2 & 3 & 2 & 8 & simple & & - \\
\hline 12 & 4 & 1 & 2 & 2 & 8 & simple & & \\
\hline 13 & 4 & 2 & 3 & 2 & 8 & simple & - & - \\
\hline 13 & 4 & 2 & 2 & 2 & 9 & simple & & \\
\hline 14 & 6 & 2 & 3 & 2 & 10 & simple & & \\
\hline 14 & 6 & 3 & 3 & 2 & 10 & simple & & \\
\hline 15 & 6 & 3 & 3 & 2 & 9 & simple & - & - \\
\hline 17 & 8 & 3 & 3 & 2 & 12 & $9-10$ & & \\
\hline 17 & 8 & 3 & 3 & 2 & 11 & $9-10$ & & \\
\hline 17 & 8 & 4 & 3 & 2 & 11 & $9-10$ & - & - \\
\hline 19 & 8 & 3 & 3 & 2 & 12 & $9-10$ & - & \\
\hline 19 & 8 & 5 & 3 & 2 & 14 & $9-10$ & - & - \\
\hline 19 & 8 & 3 & 3 & 2 & 13 & $9-11$ & - & - \\
\hline 21 & 8 & 6 & 3 & 2 & 12 & $9-11$ & - & \\
\hline 22 & 8 & 7 & 3 & 2 & 11 & $9-11$ & - & \\
\hline 22 & 8 & 7 & 3 & 2 & 14 & $9-11$ & - & \\
\hline 23 & 11 & 7 & 3 & 2 & 15 & $9-12$ & - & \\
\hline 24 & 12 & 7 & 3 & & 16 & $9-12$ & - & \\
\hline 29 & 12 & 5 & 3 & & 17 & $9-14$ & - & \\
\hline 30 & 12 & 6 & 3 & & 18 & $9-15$ & - & \\
\hline 31 & & 11 & 4 & $2,5,6$ & 18 & $9-15$ & - & - \\
\hline 31 & 17 & 10 & 3 & & 18 & $9-15$ & $\mathrm{bb}$ & + \\
\hline 32 & & 10 & 3 & & 19 & $9-15$ & $\mathrm{bb}$ & \\
\hline 33 & $20+$ & 10 & 4 & & 19 & $9-17$ & $\mathrm{bb}$ & + \\
\hline 33 & $20+$ & 10 & 4 & & 19 & $9-17$ & $\mathrm{bb}$ & + \\
\hline 33 & & 10 & 4 & & 19 & $9-17$ & $\mathrm{bb}$ & \\
\hline 35 & & & 4 & & 19 & $9-16$ & $\mathrm{bb}$ & + \\
\hline 35 & & $10+$ & 4 & $2,5,6$ & 19 & $9-17$ & $\mathrm{bb}$ & + \\
\hline 37 & & $10+$ & 4 & & 19 & $9-17$ & $\mathrm{bb}$ & + \\
\hline 40 & & & 4 & $2,5,6$ & 19 & $9-19$ & $b+b b$ & \\
\hline 40 & & & 4 & & 19 & $9-19$ & $b$ & \\
\hline 41 & & $10+$ & 4 & & 19 & $9-19$ & $b+b b$ & \\
\hline 41 & & $10+$ & 4 & & 19 & $9-19$ & $b+b b$ & + \\
\hline 41 & & $10+$ & 4 & $2,5,6$ & 19 & $9-19$ & $b+b b$ & + \\
\hline 43 & & $10_{+}$ & 4 & & 19 & $9-19$ & $b+b b$ & + \\
\hline
\end{tabular}


panded in the anterior and middle regions, tapering toward the posterior. This specimen had four small pigmented ocelli, which appeared as small reddish spots, on both sides of the prostomium posterior region (dorsal ridge). The single primary buccal grooved tentacle reached 0.5 times the length of the body. The upper peristomial lip was already well separated from the anterior region of the prostomium, the location of insertion of the buccal tentacle (Fig. 1). The first segment was achaetous, and the first notopodium was present on segment 2 and continued for the following four segments. The uncini, one to three per segment, were present from segment 3 to the pygidium, and arranged in a single row with the main fang directed forward. Branchiae and a circulatory system were absent. Because the specimen was almost transparent, it was possible to observe a pair of nephridia, probably metanephridia, on segment 3 , and the presence of orange-colored yolk in the stomach.

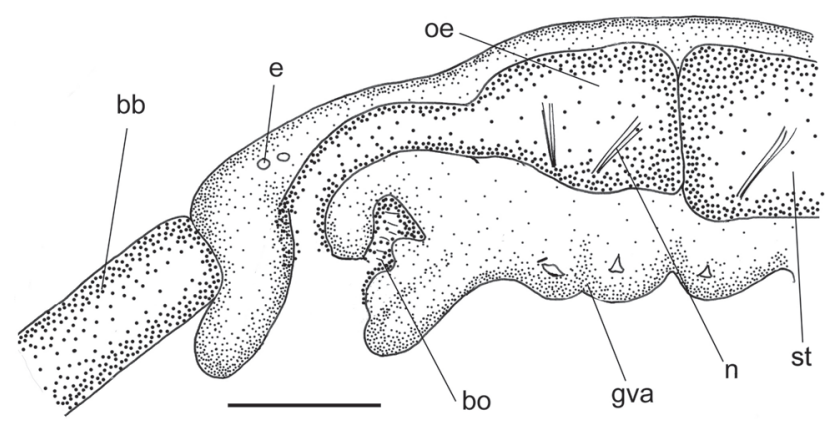

Figure 1. Nicolea uspiana: anterior end of a postlarval specimen. (bb) Buccal tentacle, (bo) buccal organ, (e) eyespot, (gva) glandular ventral area, $(n)$ notochaeta, (oe) oesophagus, (st) stomach. Scale bar: $0.1 \mathrm{~mm}$.

Some variations were observed in different specimens with 9-15 segments, such as the occurrence of more than 2 ocelli, 2-3 buccal tentacles, the first segment with notochaeta on segments $2-3$, and the number of segments with notopodia ranged from 5-10.

In 17-segmented specimens (or 11-12 segments with notopodia), the anterior and middle regions were visibly more expanded than the posterior (Figs 2 and 3), the first notopodia appeared on segment 3 , and 8 ocelli and 3-4 buccal tentacles were present (Tab. I). In this stage of development, an inversion of the uncini orientation began to occur (Fig. 7). This inverted arrangement began on the dorsal part of the torus and then extended ventrally. The inversion occurs gradually, beginning with the older segments located in the anterior region, and extending to the posterior part which contains younger segments.

After hatching at the 23-segmented stage, the number of tentacles ranged from 6-7, 11-12 ocelli, 14-15 segments with notopodia, 9-14 segments with uncini and double rows present on segments 9-12.
At about the 30-segmented stage, at least 10 buccal tentacles were present, and the first pair of branchial buds appeared on the dorsal side of the second segment, concomitantly with the development of the circulatory system. At this stage of development, the first pair of notopodia was located on segments 3-4 (Tab. I, Figs 4-5, 8-10), and the first pair of neuropodia on segment 5 . Thus, it is possible to assume that a pattern of loss of the first notopodia and neuropodia occurs in the course of development of $N$. uspiana. The first pair of notopodia, which was present on segment 2 of the postlarva, in the juvenile-adult occurred on segment 4 , and the first pair of neuropodia, which was present on segment 3 of the postlarva, in the juvenile-adult occurred on segment 5 . In addition, two new pairs of metanephridia appeared on segments 5-6, the individuals reached the maximum number of 16 segments with notopodia (beginning on segment 4 and extending to segment 19) and the first pair of branchial buds appeared on segment 2 .

The next visible morphological changes occurred when the individuals had about 35-40 segments (Tab. I, Figs 6, 10). In this stage, a second pair of branchial rami began to develop, at this time resembling two small protuberances (the first branchial pair was well developed, showing a main branch and several secondary branches arranged dichotomously). In the adult, the presence of two pairs of branchiae of different sizes, with the branchings of the second pair arising on the main branchial ramus, and the second originating directly from the dorsal part of the segment, is one of the characteristics of Nicolea Malmgren, 1866. The number of segments with inverted rows of uncini reached its maximum of 11 segments (beginning on segment 9 and extending to segment 19).

After hatching at the 35-segmented stage, no further noticeable transformations in the morphological structures were observed in the analyzed specimens. The number of buccal tentacles, ocelli and segments increased, as well as the secondary rami on the two pairs of branchiae (Tab. I, Figs 6 and 10). In adults specimens the ocelli formed a complete band along the entire length of the prostomium. In juveniles, the ocelli were displaced laterally on the prostomium, with few spots (Nogueira 2003).

\section{DISCUSSION}

The somatic growth of the organisms studied here is related to the increase of the segment numbers, which occurred slowly and apparently continuously during ontogeny.

The morphological changes observed in the development of N. uspiana are similar to those reported for other terebellids, such as $N$. uspiana are similar to those reported for other terebellids, such as Loimia medusa (Savigny, 1818) by WiLson (1928), Artacama proboscidea Malmgren, 1866 by THorson (1946), Nicolea zostericola (Oersted, 1844) by Eckelbarger (1974), Lanice conchilega (Pallas, 1766) by HeImLer (1981), Eupolymnia nebulosa (Montagu, 1818) by Bhaud \& Grémare (1988) and Ramex 


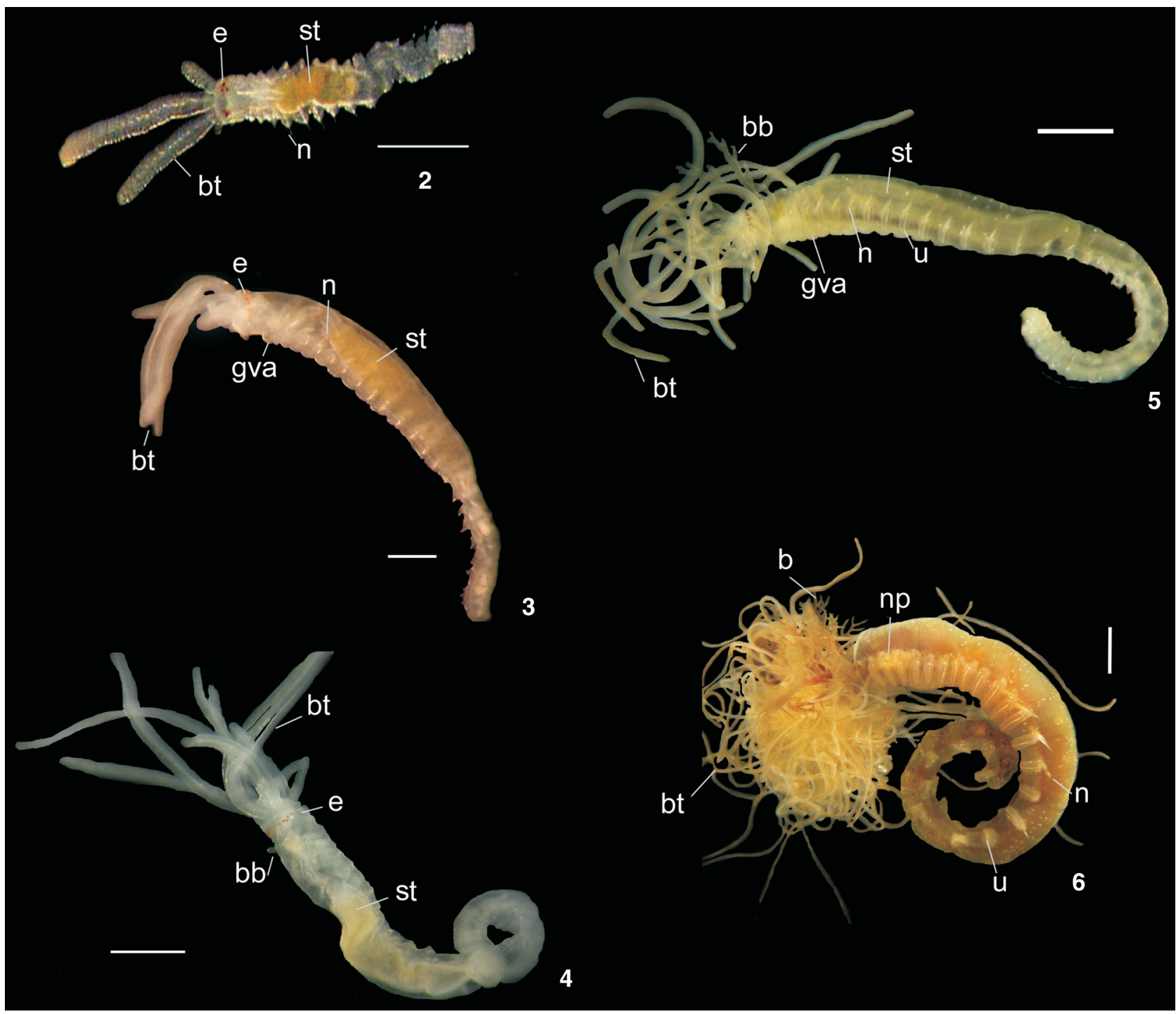

Figures 2-6. Nicolea uspiana, ontogenetic development: (2-3) postlarval specimens; (4-5) juvenile specimens; (6) adult specimen. (b) Branchia, (bb) branchial bulb, (bt) buccal tentacle, (e) eyespots, (gva) glandular ventral area, (n) notopodia, (np) nephridial papilla, (st) stomach, (u) uncini. Scale bar: 2 and $6=0.3 \mathrm{~mm}, 3=0.15 \mathrm{~mm}, 4$ and $5=0.2 \mathrm{~mm}$.

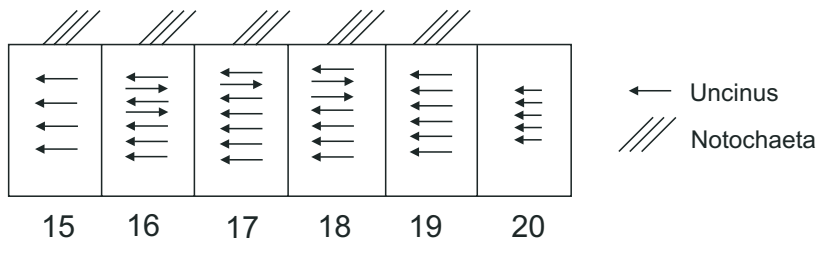

Figure 7. Nicolea uspiana: Inverted position of uncini in a "double" row on segments 15 to 18 , and a single row of uncini on segment 19. Numbers indicate the sequence of segments used. californiensis Hartman, 1944 by BLAKE (1991). The only difference noted is that, in contrast to the other species of terebellids, L. conchilega and L. medusa have a pair of statocysts on the second segment, which is important in the planktonic stage of the life cycle (Marcano \& BHAUD 1995).

As reported by BlaKe (1991), the pattern of tentacle development observed in terebellids appears to be universal. Nicolea uspiana showed the same pattern of development described in earlier studies (Wilson 1928, Eckelbarger 1974, Heimler 1981). A single buccal tentacle appears first, and subsequent tentacles appear alternately on the right and left side of the 


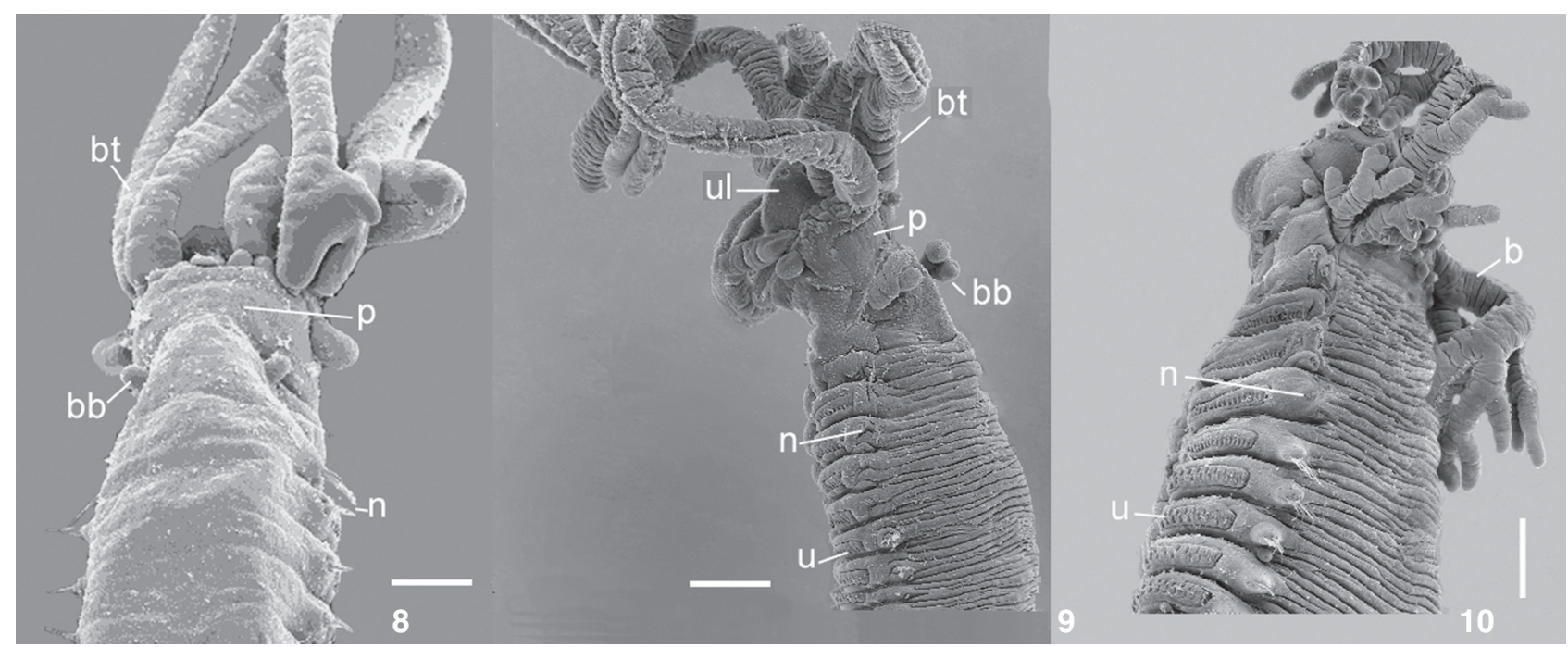

Figures 8-10. Nicolea uspiana, SEM micrographs illustrating the ontogenetic development: (8-9) juvenile specimens; (10) adult specimen. (b) Branchia, (bb) branchial bulb, (bt) buccal tentacles, (n) notopodia, (p) prostomium, (u) uncini, (ul) upper lip. Scale bar: $8=0.2 \mathrm{~mm}, 9=0.15 \mathrm{~mm}, 10=0.1 \mathrm{~mm}$.

first one, always as small intumescences, originating from the dorsal bridge in a proportion close to 1:1.

Specimens of N. uspiana show a consistent pattern of loss of the first and second notochaetae and neurochaetae during the ontogenetic development. This pattern is also seen in other terebellids (Wilson 1928, Eckelbarger 1974, Heimler 1981, Bhaud \& Grémare 1988, Blake 1991). Nicolea uspiana, $N$. zostericola, L. medusa and L. conchilega lose the first two notopodia present on segments 2 and 3; these notopodia have the typical notochaeta of the larval stage (club-shaped notochaeta), which disappear in subsequent stages of maturation. Concomitantly with the loss of notopodia, the neuropodia present on segments 3 and 4 are also lost in the specimens of these four species. In contrast, $R$. californiensis loses notopodia present on segments 2 and 3 , and only the neuropodia from segment 3 . It is always important to ensure that mature individuals are selected as types and used in the description of new species; however, understanding the patterns of reduction of the first notopodia and neuropodia is of primary importance for the taxonomy of terebellids. This is because many species, and also genera, are distinguished by on which segments the notopodia and neuropodia begin (BLAKE 1991). Thus, juveniles and adults of the same species, if collected separately, could be identified as different species, because they do not bear the first notopodia and the first neuropodia on the same segments.

The inverted arrangement of the posterior rows of uncini, also called a double row of uncini, was observed in N. uspina specimens. This change in the uncinal pattern with age and growth also occurs in other species of Terebellinae (WILSON 1928, Bhaud 1988, Bhaud \& Grémare 1988, Blake 1991, Garraffoni \&
LANA 2008). However, the avicular shape of the neurochaetae remains the same throughout the ontogenetic development. In specimens of L. medusa, WiLson (1928) reported that during growth the shape of the uncini changes from avicular (secondary teeth arranged in transverse rows above the main fang) to pectinate (five or six teeth arranged in vertical rows above the main fang). The modification of the uncinal shape that is observed in the development of specimens of Loimia spp. and Lanice spp. was considered a synapomorphy for both taxa by GARRAFFONI \& LANA (2008).

The principal ontogenetic changes in individuals of $N$. uspiana and $N$. zostericola, such as the number of tentacles, number of ocelli, appearance of the first and second branchial pair, and loss of the noto- and neuropodia, occur in the same period and sequence of development (although individuals of the former species have 19 pairs of notopods and the latter have 15). Also, during their development, representatives of $N$. zostericola lose the second pair of notopodia when they have 15 pairs, and representatives of $N$. uspiana lose the second notopodia pair when they have 19 pairs. Specimens of both species lose the second pair when they reach the maximum number of notopodia.

Although the study did not assess the early development of the larvae of Nicolea uspiana, we presume that this species has indirect development with a brief planktonic stage, characteristic of a lecithotrophic larva. We suggest this because we found no cocoons or egg masses deposited near or inside the tubes (a clear indication of direct development), and statocysts (a clear indication of indirect development, with a planktotrophic larva) were not observed on the second segment in the individuals examined. 


\section{ACKNOWLEDGMENTS}

We thank the Fundação de Amparo à Pesquisa do Estado de São Paulo for providing a postdoctoral fellowship (Proccess 05/59809-7) to the first author, and to FAEPEX/UNICAMP and CNPq (Proccess 308072/2006-5) for financial support for this project. To the Laboratório de Microscopia Eletrônica, IBUNICAMP, and the technicians Adriane Sprogis and Antônia M. de Lima. Three anonymous referees and the editor Paulo Lana are gratefully acknowledged for offering suggestions that greatly improved the paper. Janet Reid revised the English text.

\section{LITERATURE CITED}

BHAUd, M. 1988. Change in setal pattern during early development of Eupolymnia nebulosa (Polychaeta: Terebellidae) grown in simulated natural conditions. Journal of the Marine Biological Association of the United Kingdon 68 (4): 677-687.

Bhaud, M. \& A. Grémare. 1988. Larval development of the terebellid polychaete Eupolymnia nebulosa (Montagu) in the Mediterranean Sea. Zoologica Scripta 17 (4): 347-356.

BlaKe, J.A. 1991. Larval development of Polychaeta from the Northern California coast v. Ramex californiensis Hartman (Polychaeta: Terebellidae). Bulletin of Marine Science 48 (2): 448-460.

Blankensteyn, A. \& T.R. Moreno. 1999. Nova ocorrência de Nicolea venustula (Montagu) (Polychaeta, Terebellidae) na costa sul do Brasil. Revista Brasileira de Zoologia 16 (Supl. 1): 319320.

Eckelbarger, K.J. 1974. Population biology and larval development of the Terebellid Polychaete Nicolea zostericola. Marine Biology 27 (2): 101-113.

FurTado, V.V. \& M.M. MAHIQUEs. 1990. Distribuição dos sedimentos em regiões costeiras e plataforma continental do Norte do litoral do Estado de São Paulo, p. 20-26. In: ACIESP (Ed.). Simpósio de ecossistemas da costa Sul e Sudeste: estrutura, função e manejo. Águas de Lindóia, ACIESP Press, 946p. GarrafFoni, A.R.S. \& P.C. LANA. 2008. Phylogenetic relationships within Terebellidae (Polychaeta: Terebelomorpha) based on morphological characters. Invertebrate Systematics 22 (4): 605-626.

Heimler, W. 1981. Untersuchungen zur Larvalentwicklung von Lanice conchilega (Pallas, 1766) (Polychaeta, Terebellomorpha). Teil I. Entwicklungsablauf. Zoologische Jahrbücher Anatomie 106 (2): 236-277.

Marcano, G. \& M. Bhaud. 1995. New observations on the terebellid (Polychaeta) aulophore larvae on the French coast. Ophelia 43 (3): 229-244.

Mchugh, D. \& G.W. Rouse. 1998. Life history evolution of marine invertebrates: new views from phylogenetic systematics. Trends in Ecology and Evolution 13 (5): 182-186.

NogueIra, J.M.M. 2003. A new species of Paraeupolymnia Young and Kritzler, 1986 (Polychaeta, Terebellidae, Terebellinae) from Brazil. Scientia Marina 67 (4): 407-413.

Rouse, G.W. \& K. Fitzhugh. 1994. Broadcasting fables: Is external fertilization really primitive? Sex, size and larvae in sabellid polychaetes. Zoologica Scripta 23 (4) 271-312.

Thorson, G. 1946. Reproduction and larval development of Danish marine bottom invertebrates, with special reference to the planktonic larvae in the sound (Øresund). Meddelelser fra Kommissionen for Danmarks Fiskeri- og Havundersøgelser 4 (1): 1-523.

Wilson, D.P. 1928. Post-larval development of Loimia medusa Sav. Journal of the Marine Biological Association of the United Kingdon 15 (1): 129-149.

WiLSON, W.H. 1991. Sexual reproductive modes in polychaetes: classification and diversity. Bulletin of Marine Science 48 (2): 500-516.

Submitted: 30.VII.2008; Accepted: 16.III.2009.

Editorial responsibility: Paulo Lana 